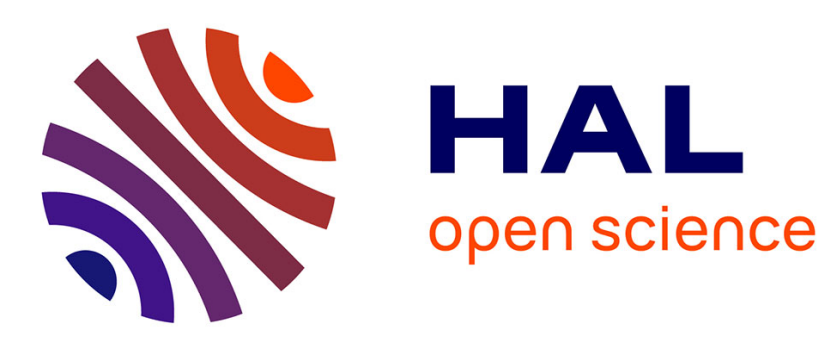

\title{
AEROGELS, A SOURCE OF ADSORBENTS, INSULATORS, CATALYSTS AND CERAMICS
}

\author{
S. Teichner
}

\section{To cite this version:}

S. Teichner. AEROGELS, A SOURCE OF ADSORBENTS, INSULATORS, CATALYSTS AND CERAMICS. Journal de Physique Colloques, 1989, 50 (C4), pp.C4-1-C4-6. 10.1051/jphyscol:1989401 . jpa-00229476

\section{HAL Id: jpa-00229476 https://hal.science/jpa-00229476}

Submitted on 1 Jan 1989

HAL is a multi-disciplinary open access archive for the deposit and dissemination of scientific research documents, whether they are published or not. The documents may come from teaching and research institutions in France or abroad, or from public or private research centers.
L'archive ouverte pluridisciplinaire HAL, est destinée au dépôt et à la diffusion de documents scientifiques de niveau recherche, publiés ou non, émanant des établissements d'enseignement et de recherche français ou étrangers, des laboratoires publics ou privés. 
AEROGELS, A SOURCE OF ADSORBENTS, INSULATORS, CATALYSTS AND CERAMICS

\author{
S.J. TEICHNER \\ Laboratoire de Thermodynamique et Cynétique Chimiques, Université \\ Claude Bernard Lyon I, 43 bd du 11 novembre 1918, F-69622 Villeurbanne \\ Cedex, France
}

Résumé - La préparation et quelques propriétés remarquables des aérogels d'oxydes inorganiques, autres que la silice, tant simples que binaires ou tertiaires, sont passées en revue.

Summary - The preparation and some remarquable properties of inorganic oxides, other than silica, aerogels, simple or binary and ternary, are reviewed.

During the First International Symposium on Aerogels, which was organized in Wurzburg (G.F.R.)/1/, it was realized that the subject is becoming enough popular to deserve a periodical reassessement of the work done in this field. Also a second symposium is now organized in Montpellier (France). The first aerogels made by Kistler /2/ were those of silica. It is still silica which is the main material produced in the form of aerogel. Its properties, thermal, acoustic, adsorbing, optical, were found so fascinating /3/ that their study is still far from being complete. New physical properties of silica aerogels are reported at the present symposium. It is not therefore surprising that only little room is, for the moment, left for the study of other aerogels. Among these, organic aerogels $/ 4 /$, zirconia aerogels /5/, cordierite aerogels /6/ and mixed aerogels of niobia and silica /7/ and silico-aluminates $/ 8 /$ are described. It seems reasonable to forecast that new properties and applications, difficult now to predict, will be found for the new non-silica aerogels and various multicomponent silica or non-silica aerogels.

\title{
SINGLE OXIDE AEROGELS
}

The purpose of this review is to bring the attention to this less studied class of non-silica aerogels. In the pioneering studies of Kistler $/ 2 /$ who, besides silica, prepared also some other aerogels the main difficulty stemmed out from the tedious procedure of washing an initial aquagel from inorganic ions and of replacing water, which is the original solvent of the precursors, by converting the aquagel into alcogel. This procedure requires large volume equipment for washing, filtering and water replacement and impeded the availability of aerogels on a commercial scale, attempted by Monsanto in St Louis (Missouri). Indeed, the low density or large volume of silica aerogels mobilizes large volume of solvents in the various equipments.

The method developped by $G$. Nicolaon and the present author $/ 9 /$ gave a new impetus to aerogels $/ 10 /$ by shortening the time required for the preparation of aerogels, from a few weeks to a few hours. Simultaneously, the technology and the equipment are now restricted to the supercritical drying in an autoclave, without any requirement for extraction, filtering and water replacement. The method may be summarized by the example of the preparation of zirconia aeroge $1 / 11 /$.

Zirconium propylate is dissolved in propanol. The addition of the stoichiometric amount of water produces hydrolysis of the organic precursor with the precipitation of zirconia (more or less hydrated) :

$\mathrm{Zr}\left(\mathrm{OC}_{3} \mathrm{H}_{7}\right)_{4}+4 \mathrm{H}_{2} \mathrm{O} \rightarrow \mathrm{Zr}(\mathrm{OH})_{4}+4 \mathrm{C}_{3} \mathrm{H}_{7} \mathrm{OH}$

This precipitation of zirconia (by hydrolysis) may be postponed by addition of an acid component like ethylacetoacetate and is only produced during the heating in the autoclave. Indeed, by drying zirconia alcogel in the autoclave, in the supercritical conditions with respect to the propanol, its conversion to an aerogel is made. This method, which was initially developed for silica aerogel with silicon methoxide as the precursor dissolved in methanol, was generalized to any oxide aerogel $/ 12 /$.

Table I gives a few examples of single oxide aerogels prepared from various organic precursors like alcoholates, their pore volumes, surface areas and the state of crystallization. 
Table I

A few examples of single oxide aerogels

\begin{tabular}{lccc}
\hline Aerogel & $\begin{array}{c}\text { Pore yolume } \\
\left(\mathrm{cm}^{3 / g)}\right.\end{array}$ & $\begin{array}{c}\text { Surfaçe area } \\
\left(\mathrm{m}^{2} / \mathrm{g}\right)\end{array}$ & Crystalline state \\
$\mathrm{SiO}_{2}$ & 11.6 & 865 & Amorphous \\
$\mathrm{Al}_{2} \mathrm{O}_{3}$ & 13.7 & 616 & Amorphous \\
$\mathrm{ZrO}_{2}$ & 4.9 & 168 & Amorphous \\
$\mathrm{MoO}_{2}$ & 7.8 & 387 & Amorphous \\
$\mathrm{MgO}^{2}$ & - & 287 & Amorphous \\
$\mathrm{Nb}_{2} \mathrm{O}_{5}$ & 12.5 & 407 & Amorphous \\
& - & 170 & Amorphous \\
\hline
\end{tabular}

a) Determined with mercury porosimeter

b) Determined by B.E.T. nitrogen adsorption

The large surface areas observed show that surface properties of aerogels may predominate over their bulk properties. In conventional, non divided solids, the surface properties are minimized. Adsorption and catalysis are linked with surface properties. It is therefore logical to experiment these properties for this new class of potential adsorbents and catalysts /12/. On the other hand, large pore volume or low apparent density of aerogels call the attention to insulating properties, thermal and acoustic $/ 3,10 /$. The fact that in some conditions of preparation aerogels may be obtained as transparent monoliths /l3/ focus their use for Cerenkov radiators (14) and glass and ceramic precursors /15, 16/. Finally, aerogels are prepared in organic solvents (1ike alcohols) and if water required for hydrolysis of the organic precursor is not in excess /13/ the resulting aerogel is usually in the amorphous state. For glasses, this state is prerequisite if a low-temperature process is applied, giving an advantage over conventional high-temperature process for production of glasses. For composite materials like catalysts, ceramics, the amorphous state of components increases their reactivity in the solid state. For multicomponent glasses and ceramics lower firing temperatures are required. For catalysts where the active phase is a product of interaction between two or more solid oxides of the aerogel it is essential to produce this interaction at low temperatures, in order to preserve the texture of the catalyst (surface area and pore volume). Indeed, catalysts sinter at high temperatures, loosing their. specific surface area and their catalytically active surface. If the oxide components of the catalyst are amorphous their interaction at low temperatures (see below) preserves high surface area and therefore provides high catalytic activity per unit mass of catalyst.

Easily reducible oxides cannot be obtained in a single state (without a support) in the aerogel form, unless they are associated with a refractory oxide aerogel carrier. For instance, organic derivatives of nickel (nickel acetate), lead (lead acetylacetonate) or copper (copper acetate) dissolved in an alcohol, hydrolyzed and evacuated in supercritical conditions give metallic and oxidized particles because of the reducing conditions in the autoclave. The metallic particles are often pyrophoric and by handing in air they are converted into oxides in a non-divided state. The corresponding metals or oxides can be however obtained in the aerogel form by association with a refractory support or carrier like silica or alumina aerogel /13/ which preserves the state of division of the metal :

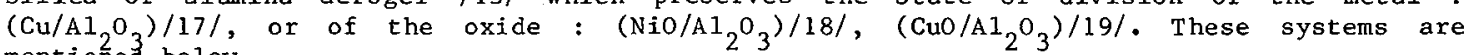
mentioned below.

Attempts were made however at the preparation of pure metal aerogels like $\mathrm{Cu}$, Pd or Au $/ 20 /$. The corresponding salts are dispersed in an organic solvent which is evacuated in supercritical conditions. The resulting $\mathrm{Cu}$ powder exhibits a surface area of $0,23 \mathrm{~m}^{2} / \mathrm{g}$ whereas supported on $\mathrm{Al}_{2} \mathrm{O}$ copper $/ 17 /$ presents a surface area of $30 \mathrm{~m} / \mathrm{g}$ for a total surface of the solid of $660 \mathrm{~m}^{2} / \mathrm{g}_{2}$ It was also claimed that pure chromia aerogels $\left(\mathrm{Cr}_{2} \mathrm{O}_{3}\right)$ with a surface area of $516-785 \mathrm{~m}^{2} / \mathrm{g}$ were prepared in methanol (21) with some safety precautions because of a possible reaction between $\mathrm{CrO}_{3}$ precursor and methanol.

Considerations concerning the variables determining high surface area and pore volume of oxide aerogels, like the nature of the organic precursor, its concentration in the alcohol and the amount of water used for hydrolysis, are given in references /12, 13, 22/. Before closing this chapter it should be mentioned that various revue articles were published on 
aerogels $/ 23,24 /$ and a general patent on aerogels, whose validity is doubtful, was recently deposited /25/. It is essentially based on the method described by the present author $/ 13 /$.

Finally, it is of interest to quote a peculiar reactivity of refractory oxides like silica or alumina under the form of aerogel. It is well known that these oxides in a conventional form are not active as catalysts. They are rather used as supports for the active partner of the catalyst, like a transition metal or its oxide. Now, it has been shown that aerogels of silica and alumina can be activated by hydrogen spillover for the catalytic reactions, at fairly low temperatures, of hydrogenation, hydrogenolysis, hydrocracking and dehydrocyclization $/ 26$ - 29/. This activation by hydrogen spillover consists in heating the aerogel at $400-450^{\circ} \mathrm{C}$ under atmospheric pressure of hydrogen in the presence of a very small amount of $\mathrm{Pt}$ supported on alumina (typically $0.5 \mathrm{mg}$ of $\mathrm{Pt}$ for $1 \mathrm{~g}$ of aerogel). Hydrogen is adsorbed and dissociated on Pt and migrates then (spills over) onto the aerogel. After this activation, which by partial surface reduction of the oxide, creates defects which are catalytic sites of various types (1ike hydrogenation and Lewis acid sites), Pt is removed by a mechanical device /29/. The oxide aerogel exhibits then various catalytic properties like hydrogenating ethylene or acetylene at $170^{\circ} \mathrm{C}$ into ethane, which are not found for the same aerogel not activated by spillover. The phenomenon of spillover of hydrogen and other adsorbed species is fully described in ref. /29/. The migration of spilled over hydrogen from Pt to the non metallic acceptor was also used to convert a silica aerogel, fully covered by methoxy groups, into silica aerogel containing only OH groups, with a simultaneous release of methane $/ 30 \%$.

$\mathrm{Si}-\mathrm{OCH}_{3}+\mathrm{H}_{\text {spill. }} \rightarrow \mathrm{Si}-\mathrm{OH}+\mathrm{CH}_{4(\mathrm{~g})}$

\section{MIXED OXIDES AND SUPPORTED AEROGELS}

It has been mentioned previously that for some oxides and metals in aerogel form a support or carrier $\left(\mathrm{Al}_{2} \mathrm{O}_{3}, \mathrm{SiO}_{2}\right)$ is required in order to preserve the divided state of the active partner. The first metal on aerogel material was nickel on alumina. It was prepared /13, 31/ by hydrolysis of a mixture of nickel acetate and aluminium sec-butylate dissolved in sec-butanol. The mixed alcogel $\mathrm{Al}_{2} \mathrm{O}_{3}-\mathrm{NiO}$ was then evacuated from the alcohol, in the autoclave, in supercritical conditions with respect to sec-butanol. These reducing conditions were maintained by cooling the autoclave in a flow of hydrogen. Table II gives the surface areas, pore volumes, metallic surface areas and mean $\mathrm{Ni}$ particles diameter for $\mathrm{Ni} / \mathrm{Al}_{2} \mathrm{O}_{3}$ aerogels with various Ni/Al ratios. For all aerogels a stoichiometric amount of water was used for hydrolysis of the precursors, according to the equations:

$\left(\mathrm{CH}_{3}-\mathrm{CH}_{2}-\right\rfloor_{\mathrm{CH}_{3}}^{\mathrm{CH}}-\mathrm{O}_{3} \mathrm{Al}+3 \mathrm{H}_{2} \mathrm{O} \rightarrow \mathrm{Al}(\mathrm{OH})_{3}+3 \mathrm{CH}_{3}-\mathrm{CH}_{2}-\mathrm{CHOH}-\mathrm{CH}_{3}$

$\left(\mathrm{CH}_{3}-\mathrm{COO}\right)_{2} \mathrm{Ni}+2 \mathrm{H}_{2} \mathrm{O} \rightarrow \mathrm{Ni}(\mathrm{OH})_{2}+2 \mathrm{CH}_{3} \mathrm{COOH}$

Table II

Nickel on alumina aerogels

Ni/Al Surfaçe area Pore yolume Metallic surface agrea Nickel particles diameter $\begin{array}{llll}\left(\mathrm{m}^{2} / \mathrm{g}\right) & \left(\mathrm{cm}^{3} / \mathrm{g}\right) \quad\left(\mathrm{m}^{2} / \mathrm{g} \mathrm{Ni}\right) \text { a) }\end{array}$

\begin{tabular}{lllll}
\hline $1 / 5$ & 510 & 7.2 & 45 & 9.1 \\
$2 / 5$ & 650 & 8.2 & 31 & 7 \\
$3 / 5$ & 330 & 18.1 & 28.5 & 6.5 \\
$4 / 5$ & 160 & 15.1 & 48.7 & 6.6 \\
1 & 160 & 10.5 & 53 & 11 \\
\hline
\end{tabular}

a) Determined by hydrogen chemisorption

b) Determined by magnetic measurements 
The highest surface areas are observed for the first two samples. The good dispersion of Ni, observed for all samples, is not maintained if an excess of water is used for hydrolysis (instead of the stoichiometric amount). Simultaneously alumina is no longer amorphous but crystallizes under the form of boehmite. This example tends to show that metallic dispersion is correlated with the amorphous state of the carrier.

By the same method $\mathrm{Cu} / \mathrm{Al}_{2} \mathrm{O}_{3}$ aerogels, catalysts of the partial hydrogenation of cyclopentadiene, were obtained, as mentioned previously $/ 17 /$. More recently Pd on alumina aerogels were prepared by a similar process /32/. They are active as catalysts of the hydrogenation of nitrobenzene to aniline.

A special mention should be made of $\mathrm{Ni}$ on $\mathrm{MoO}_{2}$ aerogel $\left(\mathrm{S}=476 \mathrm{~m}^{2} / \mathrm{G}\right)$ which shows semiconducting behaviour and exhibits a conductivity at $25^{\circ} \mathrm{C}$ in the range of 0.1 (ohm-cm) and the activation energy of conductivity of the order of $0.04 \mathrm{eV}$.

Non-refractory oxides in aerogel form, like previously metals, deserve also to be supported on a carrier, in order to exhibit high dispersion. For example, pure iron oxide aerogel $\left(\alpha-\mathrm{Fe}_{2} \mathrm{O}_{3}+\mathrm{Fe}_{3} \mathrm{O}_{4}\right)$ exhibits a surface area of $6.8 \mathrm{~m} / \mathrm{g}$ with a mean diameter of particles (determined by $\mathrm{XRD}^{2}$ ) in the range of 32.0 (for $\mathrm{Fe}_{3} \mathrm{O}_{4}$ ) to $60.0 \mathrm{~nm}$ for $\left(\alpha_{-}-\mathrm{Fe}_{2} \mathrm{O}\right.$ ) $/ 33 /$. For a mixed aerogel $\mathrm{Fe}_{3} \mathrm{O}_{4} / \mathrm{SiO}_{2}$ (with $10 \% \mathrm{Fe}$ ) the total surface area is $760 \mathrm{~m}^{2} / \mathrm{g}$ and the diameter of particles of $\mathrm{Fe}_{3} \mathrm{O}_{4}\left(\mathrm{no} \alpha-\mathrm{Fe}_{2} \mathrm{O}_{3}\right)$ is in the range of $9.0 \mathrm{~nm}$.

In the case of chromia $\left(\mathrm{Cr}_{2} \mathrm{O}_{3}\right)$ aerogel it was proposed to prepare this solid from chromium acetate dissolved in methanol in the presence of $\mathrm{Al}_{2} \mathrm{O}_{3}$-Raschig rings as collection units for the aerogel particles /34/. Another possibility is to prepare aerogel pellets (and not a powder) by addition of open-form supports to the precursor alcogels. The resulting aerogel is thus retained within the openings of a supporting structure $/ 35 /$. Conversely, $A 1,{ }^{\circ}$ aerogels supports having a high specific surface and pore volume, low bulk density and a morphology consisting of extremely thin folded ribbons or plates can be impregnated with solution of $\mathrm{TiCl}$ in $\mathrm{n}$-heptane and then with Al-sec-butylate in isobutane in order to obtain a Ziegler-Natta ethylene polymerization catalyst $/ 36 /$ in the adsorbed state and not as a liquid, soluble in the reaction medium. This solubility is a serious drawback for industrial applications of Ziegler-Natta catalysts.

It has been already mentioned that the amorphous state and a high dispersion favour the interaction between the oxides of a multicomponent aerogel. One of the best examples is the formation of a spinel $\mathrm{Al}_{2} \mathrm{O} / \mathrm{Ni}$. In the case of an aerogel $\mathrm{NiO} / \mathrm{Al}_{2} \mathrm{O}_{3}$ the spinel phase is detected already after heating to $400^{\circ} \mathrm{C} / 37 /$ whereas a mechanical mixture of crystalline $N i 0$ and $\mathrm{Al}_{2} \mathrm{O}_{3}$ requires firing temperatures in the range of $800^{\circ} \mathrm{C}$. A second point of interest in this interaction stems out from the surface properties of the spinel phase. A catalyst is active on its surface and not in the bulk. The active phase may be therefore restricted to the surface of the catalyst only. The spinel $\mathrm{Al}_{2} \mathrm{O}_{4} \mathrm{Ni}$ has been shown to behave as a very efficient catalyst of the conversion by No of isobutene into methacrylonitrile /37/. In the case of a binary aerogel $\mathrm{NiO} / \mathrm{Al}_{2} \mathrm{O}_{3}$, with a ratio $\mathrm{Ni} / \mathrm{Al}=0.5$ (corresponding to the composition of the spinel), the spinel phase is present already after preheating to $400^{\circ} \mathrm{C}$, together with the uncombined NiO and amorphous alumina.

Of course, all $\mathrm{NiO}$ can be interacted with $\mathrm{Al}_{2} \mathrm{O}_{3}$ at some higher temperature to give bulk spinel but simultaneously the solid is sintered with the loss of catalytic activity per gramme of catalyst or per gramme of nickel. However with a ratio $\mathrm{Ni} / \mathrm{Al}=0.05$ in the aerogel, preheated again at $400^{\circ} \mathrm{C}$, the formation of the spinel at the surface of alumina carrier is complete. Its catalytic activity per gramme of catalyst is practically the same as the activity of the first aerogel catalyst with $\mathrm{Ni} / \mathrm{Al}=0.5$ but its activity per gramme of nickel is 7 times higher than that of the first catalyst. In other words, Nio is much better used (or not wasted) under the form of $\mathrm{Al}_{2} \mathrm{O}_{4} \mathrm{Ni}$ when the formation of the spinel is restricted to the interface between two oxides.

Another example of the interaction between two or more components of an aerogel and of a better use of the active partner is given by $\mathrm{CuO} / \mathrm{Zno} / \mathrm{ZrO}$, ternary aerogel catalyst of the synthesis of methanol from $\left(\mathrm{CO}+\mathrm{H}_{2}\right)$ or $\left(\mathrm{CO}_{2}+\mathrm{H}_{2}\right)$ reactants $/ 38 /$. Binary aerogels $\mathrm{Zno}_{\mathrm{Al}} \mathrm{O}{ }_{3}$ and $\mathrm{CuO} / \mathrm{Al}_{2} \mathrm{O}_{3}$, where the support is alumina aerogel containing $5 \%$ of 2 no or CuO, are poor catalysts of ${ }^{\prime}$ this synthesis. The same poor behaviour is observed with the aerogel Cuo/zno (50:50) without the support or a ternary aerogel $\mathrm{CuO} / \mathrm{ZnO} / \mathrm{Al}, \mathrm{O}_{3}(5: 5: 90)$. Now, superior results concerning the catalytic activity are observed if the support is $\mathrm{ZrO}$ aerogel for a ternary $\mathrm{CuO} / \mathrm{Zno} / \mathrm{ZrO}_{2}(5: 5: 90)$ or a binary $\mathrm{CuO} / \mathrm{ZrO}_{2}(5: 95)$ composition. Zirconia by itself is barely active in the synthesis of methanol. An interaction between zirconia and Cuo is observed at $400^{\circ} \mathrm{C}$ (temperature of the pretreatment giving the highest catalytic activity). When the 
amount of CuO (or $\mathrm{ZnO}$ for the ternary catalyst) is increased with respect to $\mathrm{ZrO}$ (up to 40 \%) no improvement of the activity is found. Again, an interaction restricted to the interface between two (or three) solid phases is sufficient in the development of surface properties, here involved in catalysis.

The fluidization of aerogel catalysts in a dynamic reactor removes all difficulties in the use of these powdered catalysts on a commercial scale $/ 39 /$.

However a total interaction (bulk) is also favoured between the components of an aerogel. It may require higher temperature than the surface interaction but conventional non-aerogel components require still much higher firing temperatures and a longer time to give a bulk interaction. This is, in particular, the case of the superconductor ceramics $\mathrm{Y} \mathrm{Ba}_{2} \mathrm{Cu}_{3} \mathrm{O}_{7-\mathrm{x}}$, which is easily synthetized by heating the precursor aerogel, as described at this symposium $140 /$, at lower temperatures and in a shorter time than for the mechanical mixture of crystallized precursurs, oxides or carbonates.

Even if the final crystallization is not desired, which is the case of glasses, the aerogel leads to an easier densification, (in a shorter time), at a lower firing temperature and at a lower pressure applied. This is in particular observed in low-temperature cordierite glass (magnesium silico-aluminate) made by aerogel process $/ 41 /$.

Many binary or ternary aerogels were prepared as catalysts, but it is not the purpose of this revue to examine their properties. The catalytic activity was only considered here as a tool in labelling surface properties of aerogels and derived solids.

In conclusion, a tremendous amount of research work has still to be done in order to explore properties and applications of non-silica aerogels. Electrical conductor aerogels, supraconductor aerogel precursors, new adsorbents, aerogel precursors for new types of glasses and ceramics, exhibiting simultaneously peculiar isolating properties (acoustic and thermal) and new aerogel catalysts are the non-exhaustive examples of the field to be developped at the 3d I.S.A.

\section{REFERENCES}

/1/ First International Symposium on Aerogels, J. Fricke Ed., Springer Proc. in Phys., Vol. 6, Wïrzburg, 1986.

/2/ Kistler, S.S., Nature, 127 (1931) 741, J. Phys. Chem., 34 (1932) 52.

/3/ Fricke, J., J. Non-Cryst. Solids, 100 (1988) 169.

/4/ Pekala, R.W., This Symposium.

/5/ Vesteghem, H., Jaccon, T., and Lecomte, A., This Symposium.

/6/ Vesteghem, H., Fargeot, D., and Dauger, A., This Symposium.

$/ 7 /$ Bouaziz, J., Sempere, R., Bonnet, D. and Sivade, A., This Symposium.

/8/ Chaput, A., Boilot, J.P. and Dauger, A., This Symposium.

/9/ Nicolaon, G.A. and Teichner, S.J., Bul1. Soc. Chim. France, 1968, 1900, 1906.

$/ 10 /$ Fricke, J., Proc. of the lst Int. Symp. on Aerogels, J. Fricke Ed., Springer Proc. in Phys., Vol. 6, 1986, p. 2-19.

/11/ Vicarini, M.A., Nicolaon, G.A. and Teichner, S.J., Bul1. Soc. Chim. France, 1970, 1651 .

/12/ Teichner, S.J., Proc. of the 1st Int. Symp. on Aerogels, J. Fricke Ed., Springer Proc. in Phys., Vo1. 6, 1986, p. 22.

/13/ Teichner, S.J., Nicolaon, G.A., Vicarini, M.A. and Gardes, G.E.E., Adv. Coll. Interf. Sci., $\underline{5}$ (1976) 245 .

/14/ Cantin, M., Casse, M., Koch, L., Jouan, R., Mestreau, P., Rouseel, D., Bonnin, F., Moutel, J., Teichner, S.J., J. Nucl. Instr. Meth., 118 (1974) 177.

/15/ Zarzycki, J., Proc. Int. Conf. Ultrastruct. Process, Ceram. Glasses, Compos. L.L. Hench and D.R. Ulrich Eds, J. Wiley, New-York 1983, p. 27.

/16/ Phalippou, J., Woignier, T. and Zarzycki, J., Proc. Int. Conf. Ultrastruct. Process. Ceram. Glasses Compos., L.L. Hench and D.R. Ulrich Eds, J. Wiley, New-York, 1983, p. 70.

/17/ Pajonk, G., Taghavi, M.B. and Teichner, S.J., Bul1. Soc. Chim. France, 1975, 483.

/18/ Gardes, G.E.E., Pajonk, G., and Teichner, S.J., Bul1. Soc. Chim. France, 1976, 1321.

/19/ Centi, G., Trifiro, F., Vaccari, A., Pajonk, G.M. and Teichner, S.J., Bu11. Soc. Chim. France, 1981, 290 .

/20/ Armor, J.N. and Car1son, E.J., U.S. Patent 4,615,736, (Oct. 7, 1986) and Mater. Lett., 4 (1986) 376 .

/21/ Armor, J.N., Carlson, , E.J. and Conner, W.C., React. Solids, 3 (1987) 155.

/22/ Armor, J.N. and Carlson, E.J., J. Mater. Sci., 22 (1987) 2549.

/23/ Gowda, G. and Harrisson, T., J. Can. Ceram. Soc., 55 (1986) 68.

/24/ Smirnov, B.M., Usp. Fiz. Nauk, 152 (1987) 133.

/25/ Cheng, Ch. P. and Jacobucci, P.A., Eur. Pat. Appl., 149,816 (July 31, 1985). 
/26/ Lacroix, M., Pajonk, G. and Teichner, S.J., Study Surf. Sci. Catal., 7 (1981) 279.

/27/ Teichner, S.J., Pajonk, G.M. and Lacroix, M., in "Surface Properties and Catalysis by Non-metals", J.P. Bonnelle et al. Ed., Reidel Pub. Co., Amsterdam 1983, p. 45.

/28/ Lacroix, M., Pajonk, G. and Teichner, S.J., J. Catalysis, 101 (1986) 314.

129/ Conner, W.C., Pajonk, G.M. and Teichner, S.J., Adv. Catal., 34 (1986) 1.

/30/ Bianchi, D., Lacroix, M., Pajonk, G. and Teichner, S.J., J. Catalysis, 68 (1981) 411.

/31/ Gardes, G.E.E., Pajonk, G.M. and Teichner, S.J., J. Catalysis, 33 (1974) 145.

132/ Armor, J.N., Carlson, E.J. and Zambri, P.M., Appl. Catal., 19 (1985) 339, U.S. Pat. $4,469,816$ (Sept. 4, 1984).

/33/ Blanchard, F., Pommier, B., Reymond, J.P. and Teichner, S.J., Stud. Surf. Sci. Catal., 16 (1983) 395.

134/ Carlson, E.J. and Armor, J.N., Ger. Offen. DE 3,534,970 (Apr. 24, 1986).

/35/ Armor, J.N. and Carlson, E.J., Appl. Catal., 19 (1985) 327.

/36/ Fanel1i, A.J. and Price, A.K., U.S. Pat. 4,478,987 (Oct. 23, 1984).

137/ Sayari, A., Ghorbel, A., Pajonk, G.M. and Teichner, S.J., Bul1. Soc. Chim. France, 1981, $7,24$.

/38/ Pommier, B. and Teichner, S.J., Proc. 9th. Int. Congr. Catal., Calgary 1988, M.J. Philips and M. Ternan Eds, The. Chem. Inst. of Canada Pub., Ot tawa 1988, p. 610 .

139/ Chaouki, J., Chavarie, C., Klvana, D. and Pajonk, G.M., Powder Technol., 43 (1985) 117.

/40/ Pomier, B., Teichner, S.J., Lejay, P., Sulpice, A. and Tournier, R., This Symposium.

/41/ Vesteghem, H., Di Giampaolo, A.R. and Dauger, A., J. Mater. Sci. Lett., 6 (1987) 1187. 